\title{
ANALISIS PENERAPAN PERHITUNGAN TAX PLANNING DENGAN METODE NET DAN METODE GROSS UP TERHADAP PPH BADAN
}

\author{
Mahwiyah \\ Universitas Pamulang \\ Mahwiyah_99@ymail.com
}

\begin{abstract}
The purpose of this study was to determine whether there is a comparison between the calculation of the net method and the tax gross-up method (income tax) body transform and minimize the tax owed. The method of analysis used descriptive qualitative method, in which the author takes the data relating to Income Tax Article 21, including the recap salary then analyze the components in question are salary and benefits. After doing the analysis, it can be concluded that the presence of Tax Planning is the company can do a comparison of income tax (VAT) of Article 21 by using Method Net or Gross-up method is the most efficient method is to gross-up or giving an allowance of tax payable, from the comparison of the two calculations are done, the gross-up method or allowances payable for the tax efficiency of the Income Tax (VAT) amounting Rp3.141.683 Agency for 2010, Rp1.513.929 for 2011, and Rp1.846.733 for 2012.
\end{abstract}

Keywords: Article 21 Income Tax, Corporate Income Tax, Net Methods and Gross Up Method

\section{PENDAHULUAN}

Perencanaan pajak (Tax Planning) adalah proses mengorganisasi usaha wajib pajak atau kelomp[ok wajib pajak sedemikian rupa utang pajaknya, baik pajak penghasilan maupun pajak-pajak lainnya, berada dalam posisi yang minimal, sepanjang hal itu memungkinkan, sepanjang hal itu dimungkinkan baik oleh ketentuan peraturan perundang-undangan perpajakan maupun secara komersial.

Menurut Harnanto (2013:3): "Perencanaan pajak adalah Suatu proses pengintegrasian usaha-usaha wajib pajak atau sekelompok wajib pajak untuk meminimalisasikan beban atau kewajiban pajaknya, baik yang berupa pajak penghasilannya maupun pajak-pajak yang lainnya melalui pemanfaatan fasilitas perpajakan, penghematan pajak (tax saving), dan penghindaran pajak (tax 
avoidance) yang sesuai dengan atau tidak menyimpang dari ketentuan-ketentuan perundang-undangan perpajakan”.

Pajak penghasilan $(\mathrm{PPh})$ pasal 21 merupakan pajak atas penghasilan berupa gaji, upah honorarium, tunjangan, dan pembayaran lain dengan nama dan bentuk apapun sehubung dengan pekerjaan atau jabatan, jasa dan kegiatan yang dilakukan oleh wajib pajak orang pribadi dalam negeri.

Menurut Mardiasmo (2009:162) “Pajak Penghasilan Pasal 21 adalah Pajak atas penghasilan berupa gaji, upah, honorarium, tunjangan dan pembayaran lain dengan nama dan dalam bentuk apa pun sehubung dengan pekerjaan atas jabatan, jasa, dan kegiatan yang dilakukanpleh orang pribadi ".

Menurut UU No. 28 Tahun 2007 tentang ketentuan umum dan tata cara perpajakan, pasal 1 dan 3, Badan adalah sekumpulan orang atau modal yang merupakan kesatuan baik yang melakukan usaha maupun yang tidak melakukan usaha yang meliputi perseroan terbatas, perseroan komanditer, perseroan lainnya, BUMN atau BUMD dengan nama dan dalam bentuk apapun, firma, kongsi kopersi, dana pensiun, persekutuan, perkumpulan, yayasan, organisasi masa, organisasi sosial politik atau organisasi lainnya, lembaga dan bentuk badan lainnya.

Agus Setiawan (2008:3) “ Badan Usaha adalah sekumpulan orang dan / atau modal yang merupakan kesatuan, baik yang melakukan usaha maupun yang tidak melakukan usaha, yang meliputi perseroan terbatas, perseroan komanditer, perseroan lainnya, badan usaha milik negara atau badan usaha milik daerah dengan nama dan dalam bentuk apa pun, firma, kongsi, koperasi, dana pensiun, persekutuan, perkumpulan, yayasan, organisasi massa, organisasi sosial politik, atau organisasi lainnya, lembaga dan bentuk badan lainnya termasuk kontrak investasi kolektif dan bentuk usaha tetap (Pasal 1 angka 3 UU No. 28 Tahun 2007).

Menurut Chairil Anwar Pohan $(2011 ; 1)$ perencanaaan pajak untuk pph pasal 21 setidaknya dapat dilakukan dengan memilih perhitungan pph pasal 21. Ada tiga metode yang dapat dipilih oleh perusahaan dalam menghitung pph pasal 21 , yaitu: 
1. Gross Method (PPh pasal 21 ditanggung oleh karyawan)

Merupakan metode pemotongan pajak dimana karyawan menanggung sendiri jumlah pajak penghasilannya, yang biasanya dipotong langsung dari gaji karyawan yang bersangkutan.

2. Net Method (PPh pasal 21 yang ditanggung oleh perusahaan)

Merupakan metode pemotongan pajak dimana perusahaan menanggung pajak karyawannya.

3. Gross-Up Method (Tunjangan pajak yang digross up)

Metode pemotongan pajak dimana perusahaan memberikan tunjangan pajak yang jumlahnya sama besar dengan jumlah pajak yang akan dipotong dari karyawan.

\section{TELAAH LITERATUR DAN PENGEMBANGAN HIPOTESIS}

\section{Tinjauan Teori}

\section{Pajak Penghasilan Pasal 21}

Pajak penghasilan $(\mathrm{PPh})$ pasal 21 merupakan pajak atas penghasilan berupa gaji, upah honorarium, tunjangan, dan pembayaran lain dengan nama dan bentuk apapun sehubung dengan pekerjaan atau jabatan, jasa dan kegiatan yang dilakukan oleh wajib pajak orang pribadi dalam negeri.

Menurut Mardiasmo (2009:162) “ Pajak Penghasilan Pasal 21 adalah Pajak atas penghasilan berupa gaji, upah, honorarium, tunjangan dan pembayaran lain dengan nama dan dalam bentuk apa pun sehubung dengan pekerjaan atas jabatan, jasa, dan kegiatan yang dilakukanpleh orang pribadi ".

\section{Perencanaan Pajak}

Perencanaan pajak (Tax Planning) adalah proses mengorganisasi usaha wajib pajak atau kelomp[ok wajib pajak sedemikian rupa utang pajaknya, baik pajak penghasilan maupun pajak-pajak lainnya, berada dalam posisi yang minimal, sepanjang hal itu memungkinkan, sepanjang hal itu dimungkinkan baik 
oleh ketentuan peraturan perundang-undangan perpajakan maupun secara komersial.

Menurut Harnanto (2013:3): "Perencanaan pajak adalah Suatu proses pengintegrasian usaha-usaha wajib pajak atau sekelompok wajib pajak untuk meminimalisasikan beban atau kewajiban pajaknya, baik yang berupa pajak penghasilannya maupun pajak-pajak yang lainnya melalui pemanfaatan fasilitas perpajakan, penghematan pajak (tax saving), dan penghindaran pajak (tax avoidance) yang sesuai dengan atau tidak menyimpang dari ketentuan-ketentuan perundang-undangan perpajakan".

\section{Pajak Penghasilan Badan}

Menurut UU No. 28 Tahun 2007 tentang ketentuan umum dan tata cara perpajakan, pasal 1 dan 3, Badan adalah sekumpulan orang atau modal yang merupakan kesatuan baik yang melakukan usaha maupun yang tidak melakukan usaha yang meliputi perseroan terbatas, perseroan komanditer, perseroan lainnya, BUMN atau BUMD dengan nama dan dalam bentuk apapun, firma, kongsi kopersi, dana pensiun, persekutuan, perkumpulan, yayasan, organisasi masa, organisasi sosial politik atau organisasi lainnya, lembaga dan bentuk badan lainnya.

Agus Setiawan (2008:3) “ Badan Usaha adalah sekumpulan orang dan / atau modal yang merupakan kesatuan, baik yang melakukan usaha maupun yang tidak melakukan usaha, yang meliputi perseroan terbatas, perseroan komanditer, perseroan lainnya, badan usaha milik negara atau badan usaha milik daerah dengan nama dan dalam bentuk apa pun, firma, kongsi, koperasi, dana pensiun, persekutuan, perkumpulan, yayasan, organisasi massa, organisasi sosial politik, atau organisasi lainnya, lembaga dan bentuk badan lainnya termasuk kontrak investasi kolektif dan bentuk usaha tetap (Pasal 1 angka 3 UU No. 28 Tahun 2007). 


\section{METODE PENELITIAN DAN PEMBAHASAN}

\section{Metode yang digunakan penulis dalam menyusun penelitian ini adalah}

sebagai berikut:

\section{Metode Analisis Deskriptif}

Metode analisis deskriptif yaitu metode yang bertujuan untuk mengumpulkan data dan informasi yang dapat menggambarkan keadaan objek penelitian dan menyederhanakannya untuk menjelaskan masalah dan pemecahannya agar dapat dibaca dan mudah dimengerti.

\section{Metode Analisis Kualitatif}

yaitu metode yang tidak dapat di ukur dengan angka-angka ataupun ukuran lain yang bersifat eksak. Penelitian kualitatif bisa diartikan sebagai riset dan cenderung menggunakan analisis dengan pendekatan induktif

Metode penelitian kuantitatif dapat diartikan sebagai metode penelitian yang berlandaskan pada filsafat postpositivisme, digunakan untuk meniliti pada kondisi objek yang alamiah (sebagai lawannya adalah ekspeimen) dimana peneliti adalah sebagai instrumen kunci, pengambilan sampel sumber data yang dilakukan secara purposive dan snowbaal, teknik pengumpulan dengan trianggulasi ( gabungan ), analisis data bersifat induktif / kualitatif, dan hasil peneltian kualitatif lebih menekan makna dari pada generalisasi (Sugiyono, 2010:14).

\section{HASIL PENELITIAN DAN PEMBAHASAN}

\section{Hasil}

\section{Penerapan perhitungan PPh Pasal 21 dengan Metode Net}

Salah satu karyawan perusahaan pada bulan Januari 2010, atas nama Amir jabatan directur dengan gaji sebulan Rp 120.000.000,- setahun dan berstatus kawin beranak dua (K/2) dengan biaya jabatan setahun makimal Rp 6.000.000 dan membayar iuran pensiun sebesar 3.7\% dari gaji pokok.

Maka perhitungannya sebagai berikut : 
Gaji sebulan

Tunjangan Makan

Tunjangan kesehatan

Uang Lembur

THR

JKK 0,24\% x Rp 120.000.000

JKM 0,3\% x Rp 120.000.000

Penghasilan Bruto

Pengurang:

Biaya jabatan:

$5 \% \times \operatorname{Rp} 134.788 .000,00=\operatorname{Rp} 6.000 .000,00$

Iuran Pensiun

$\underline{\mathrm{Rp} \quad 300.000,00}$

Rp $\quad 6.300 .000,00$

Penghasilan Neto setahun

PTKP (K/0) setahun

Untuk WP sendiri

Rp 15.840.000,00

Tambahan WP kawin

Tambahan 2 orang anak

Rp $1.320 .000,00$

Rp 2,640.000,00

$\underline{\mathrm{Rp} 19.800 .000,00}$

Penghasilan Kena Pajak setahun Rp115.588.000,00

PPh Pasal 21 Terutang

$5 \%$ x Rp 50.000.000,00

$=\operatorname{Rp} 2.500 .000,00$

$15 \%$ x Rp 65.588.000,00

$=\underline{\mathrm{RP} 9.838 .200,00}$

$\mathrm{PPh}$ Pasal 21 setahun $=$
Rp 120.000.000,00

Rp 7.200.000,00

Rp $\quad 3.600 .000,00$

$\mathrm{Rp} \quad 240.000,00$

Rp 10.000.000,00

$\mathrm{Rp} \quad 288.000,00$

$\underline{\mathrm{Rp} \quad 360.000,00}$

Rp 141.688.000,00

PPh Pasal 21 sebesar Rp 12.338.200,00 ditanggung dan dibayar oleh perusahaan dan jumlah tersebut tidak dapat dikurangkan dari Penghasilan Bruto pemberi kerja dan bukan merupakan penghasilan yang dikenakan pajak 
kepadaAmir. Jadi, gaji yang dibawa pulang Amir adalah sebesar Rp120.00.000,00 per tahun.

Tabel 4.1

Perhitungan PPh Pasal 21 Tahun 2010

Dengan Metode Net Basis

\begin{tabular}{|c|c|c|c|c|c|c|c|c|c|c|}
\hline \multirow{2}{*}{$\begin{array}{c}\text { Nama } \\
\text { Karyawan } \\
\end{array}$} & \multirow{2}{*}{ Status } & \multirow{2}{*}{$\begin{array}{c}\text { Gaji } \\
\text { Setahun }\end{array}$} & \multirow[t]{2}{*}{ THR } & \multirow{2}{*}{$\begin{array}{l}\text { penghasilan } \\
\text { Bruto Setahun }\end{array}$} & \multicolumn{2}{|c|}{ Pengurangan } & \multirow{2}{*}{$\begin{array}{l}\text { Penghasilan } \\
\text { Neto Setahun }\end{array}$} & \multirow{2}{*}{$\begin{array}{l}\text { PTKP } \\
\text { Setahun } \\
\end{array}$} & \multirow[t]{2}{*}{ PKP } & \multirow{2}{*}{$\begin{array}{l}\text { PPh 21 } \\
\text { Setahun }\end{array}$} \\
\hline & & & & & B. Jabatan & Iuran & & & & \\
\hline Amir & $\mathrm{K} / 2$ & $131,688,000$ & $10,000,000$ & $141,688.000$ & $6,000,000$ & 300,000 & 135.388 .000 & $19,800,000$ & 115.588 .000 & 12.338 .200 \\
\hline bbas & $\mathrm{K} / 3$ & $192,012,000$ & $15,000,000$ & $207,012,000$ & $6,0000,000$ & 300,000 & $200,712,000$ & $21,120,000$ & $179,592,000$ & $21,938.800$ \\
\hline udi & $\mathrm{K} / 2$ & $107,558.400$ & $8,000,000$ & 115.558 .400 & $4.800,000$ & 300,000 & $110,458.400$ & $19,800,000$ & $90,658.400$ & 8.598 .760 \\
\hline Kiki & $\mathrm{K} / 2$ & $107,558.400$ & $8,000,000$ & 115.558 .400 & $4,800,000$ & 300,000 & $110,458,400$ & $19,800,000$ & $90,658.400$ & 8.598 .760 \\
\hline Ridwan & $K / 2$ & $50,853.840$ & $3,300,000$ & 54.153 .840 & $1.980,000$ & 300,000 & $51,873,840$ & $19,800,000$ & $32,073,840$ & $1,603,692$ \\
\hline Agus & $\mathrm{K} / 3$ & $37,582.560$ & $2.200,000$ & $39,782.560$ & $1,320,000$ & 300,000 & 38.162 .560 & $21,120,000$ & $17,042.560$ & 852.128 \\
\hline Heri & TK10 & $37,582.560$ & $2.2000,000$ & $39,782.560$ & $1,320,000$ & 300,000 & 38.162 .560 & $15,840,000$ & 22.322 .560 & 1.116 .128 \\
\hline Mimi & TK/0 & 37.582 .560 & $2.2000,000$ & 39.782 .560 & $1,320,000$ & 300.000 & 38.162 .560 & $15.840,000$ & $22,322.560$ & 1.116 .128 \\
\hline Ekno & $\mathrm{K} / 2$ & $37,582.560$ & $2.2000,000$ & 39.782 .560 & $1,320,000$ & 300,000 & 38.162 .560 & $19,800,000$ & 18.362 .560 & 918.128 \\
\hline Suriati & TK/0 & 4.218.200 & $2,750,000$ & 46.968 .200 & $1,650,000$ & 300,000 & $45,018.200$ & $15,840,000$ & $29,178.200$ & $1,458.910$ \\
\hline Sutrisno & $\mathrm{K} / 3$ & $50,853.840$ & $3,300,000$ & $54,153.840$ & $1.980,000$ & 300,000 & 51.873 .840 & $21,120,000$ & $30,753.840$ & $1.537,692$ \\
\hline Samsul & $\mathrm{K} / 2$ & $57,489,480$ & $3,850,000$ & $61.339,480$ & 2310,000 & 300,000 & $58,729,480$ & $19,800,000$ & $38,929,480$ & $1,946.474$ \\
\hline Tri & $K / 3$ & $37,582.560$ & $2.2000,000$ & $39,782.560$ & $1,320,000$ & 300,000 & 38.162 .560 & $21.120,000$ & $17,042.560$ & 852.128 \\
\hline Vono & $\mathrm{K} / 3$ & $37,582.560$ & $2.2000,000$ & 39.782 .560 & $1,320,000$ & 300,000 & 38.162 .560 & $21,120,000$ & $17,042.560$ & 852.128 \\
\hline putra & $\mathrm{K} / 2$ & 37.582 .560 & $2,200,000$ & $39,782.560$ & $1,320,000$ & 300,000 & 38.162 .560 & $19,800,000$ & 18.362 .560 & 918.128 \\
\hline TOTAL & & $1,005,310,080$ & $69,600,000$ & $1,074,910,080$ & $38.760,000$ & $4,500,000$ & $1,031,650,080$ & $291,720,000$ & $739,930,080$ & 64.646 .184 \\
\hline
\end{tabular}

Tabel 4.2

Perhitungan PPh Pasal 21 Tahun 2011

Dengan Metode Net Basis

\begin{tabular}{|c|c|c|c|c|c|c|c|c|c|c|}
\hline \multirow{2}{*}{$\begin{array}{c}\text { Nama } \\
\text { Karyawan }\end{array}$} & \multirow{2}{*}{ Status } & \multirow{2}{*}{$\begin{array}{c}\text { Gaji } \\
\text { Setahun }\end{array}$} & \multirow[t]{2}{*}{ THR } & \multirow{2}{*}{$\begin{array}{c}\text { penghasilan } \\
\text { Bruto Setahun }\end{array}$} & \multicolumn{2}{|c|}{ Pengurangan } & \multirow{2}{*}{$\begin{array}{l}\text { Penghasilan } \\
\text { Neto Setahun }\end{array}$} & \multirow{2}{*}{$\begin{array}{c}\text { PTKP } \\
\text { Setahun } \\
\end{array}$} & \multirow[t]{2}{*}{ PKP } & \multirow{2}{*}{$\begin{array}{l}\text { PPh } 21 \\
\text { Setahun } \\
\end{array}$} \\
\hline & & & & & B. Jabatan & Iuran & & & & \\
\hline Amir & $\mathrm{K} / 2$ & 192.012 .000 & $15,000,000$ & $207,012,000$ & $6,000,000$ & 300,000 & 200.712 .000 & $19,800,000$ & $180.912,000$ & 22.136 .800 \\
\hline Abbas & $\mathrm{K} / 3$ & $252.336,000$ & $20,000,000$ & $272.336,000$ & $6,000,000$ & 300,000 & $266,036,000$ & $21,120,000$ & 244.916 .000 & $31.737,400$ \\
\hline Budi & $\mathrm{K} / 2$ & $131,688.000$ & $10,000,000$ & $141,688.000$ & $6,000,000$ & 300,000 & 135.388 .000 & $19,800,000$ & 115.588 .000 & 12.338 .200 \\
\hline Kiki & $\mathrm{K} / 2$ & 131.688 .000 & $10,000,000$ & 141.688 .000 & $6,000,000$ & 300.000 & $135,388.000$ & 19.800 .000 & 115.588 .000 & 12.338 .200 \\
\hline Ridwan & $\mathrm{K} / 2$ & $55.679,760$ & $3,700,000$ & 59.379 .760 & 2.220 .0000 & 300,000 & 56.859 .760 & $19,800,000$ & $37,059.760$ & 1.852 .988 \\
\hline Agus & $\mathrm{K} / 3$ & $41.202,000$ & 2.500 .000 & 43.702 .000 & 1.500 .000 & 300.000 & 41.902 .000 & $21.120,000$ & $20.782,000$ & $1,039.100$ \\
\hline Heri & $\mathrm{TK} / 0$ & 41.202 .000 & 2.500 .000 & 43.702 .000 & $1.500,000$ & 300,000 & 41.902 .000 & $15.840,000$ & $26,062,000$ & 1.303 .100 \\
\hline Mimi & $\mathrm{TK} / 0$ & $39,794,038$ & 2.383 .300 & $42.177,338$ & $1,429.980$ & 300,000 & $40,477,358$ & $15,840,000$ & 24.607 .358 & 1.230 .368 \\
\hline Ek0 & $\mathrm{K} / 2$ & 41.202 .000 & $2.500,000$ & 43.702 .000 & $1.500,000$ & 300,000 & 41.902 .000 & $19,800,000$ & $22.102,000$ & 1.105 .100 \\
\hline Suriati & $\mathrm{TK} / 0$ & 47.234 .400 & $3,000,000$ & 50.234 .400 & 1.800 .000 & 300.000 & 48.134 .400 & 15.840 .000 & 32.294 .400 & 1.614 .720 \\
\hline Sutrisno & $\mathrm{K} / 3$ & $55.679,760$ & $3.700,000$ & $59,379,760$ & 2.220 .000 & 300.000 & $56,859,760$ & 21.120 .000 & 35.739 .760 & 1.786 .988 \\
\hline Samsul & $\mathrm{K} / 2$ & 62.315 .400 & $4.250,000$ & 66.565 .400 & 2.550 .000 & 300,000 & $63,715.400$ & $19,800,000$ & 43.915 .400 & 2.195 .770 \\
\hline Tri & $\mathrm{K} / 3$ & $41.202,000$ & 2.500 .000 & 43.702 .000 & 1.500 .000 & 300.000 & 41.902 .000 & 21.120 .000 & 20.782 .000 & $1,039.100$ \\
\hline Yono & $\mathrm{K} / 3$ & 41.202 .000 & 2.500 .000 & 43.702 .000 & 1.500 .000 & 300,000 & 41.902 .000 & $21.120,000$ & 20.782 .000 & $1,039.100$ \\
\hline putra & $\mathrm{K} / 2$ & 41.202 .000 & 2.500 .000 & 43.702 .000 & $1.500,000$ & 300,000 & $41,902.000$ & $19,800,000$ & $22.102,000$ & 1.105 .100 \\
\hline TOTAL & & 1.215 .639 .358 & $87,033,300$ & 1.302 .672 .658 & $43.219,980$ & $4.500,000$ & 1.254 .952 .678 & $291,720,000$ & 963.232 .678 & 93.862 .034 \\
\hline
\end{tabular}


Tabel 4.3

Perhitungan PPh Pasal 21 Tahun 2012

Dengan Metode Net Basis

\begin{tabular}{|c|c|c|c|c|c|c|c|c|c|c|}
\hline \multirow{2}{*}{\begin{tabular}{|c|} 
Nama \\
Karryawan \\
\end{tabular}} & \multirow{2}{*}{ Status } & \multirow{2}{*}{$\begin{array}{c}\text { Gajil } \\
\text { Setahun }\end{array}$} & \multirow[t]{2}{*}{ THR } & \multirow{2}{*}{$\begin{array}{l}\text { penghasilan } \\
\text { Brutu Setahun }\end{array}$} & \multicolumn{2}{|c|}{ Pengurangan } & \multirow{2}{*}{$\begin{array}{l}\text { Penghasilan } \\
\text { Neto Setahun }\end{array}$} & \multirow{2}{*}{$\begin{array}{l}\text { PTKP } \\
\text { Setahun }\end{array}$} & \multirow[t]{2}{*}{ PKP } & \multirow{2}{*}{$\begin{array}{l}\text { PPh21 } \\
\text { Setahun }\end{array}$} \\
\hline & & & & & B. Jabatal & Iuraill & & & & \\
\hline iir & $\mathrm{K} / 2$ & 1523360,000 & $20,000,000$ & 2712356,000 & $6,000,000$ & 300,000 & $266,036,000$ & $19,800,000$ & $246.2660,000$ & 31,93 \\
\hline bas & $K / 3$ & $297,466.600$ & 1200000000 & $298,460,600$ & $6,000,000$ & 300,000 & $292.165,600$ & $21,120,000$ & 271,0,45,000 & 37,76 \\
\hline adi & $\mathrm{K} / 2$ & $|15,8171,600|$ & $12,000,000$ & $167,817,600$ & $6,000,000$ & 300,000 & $161,517,600$ & $19,800,000$ & $141,717,600$ & \\
\hline Kilki & $\mathrm{K} / 2$ & $|15,817,600|$ & $12,000,000$ & $167,817,600$ & $6,0,00,000$ & 300,000 & $61517 \mathrm{~cm}$ & 15000000 & $141,717,000$ & \\
\hline Ridwan & K/2 & $60,503,6800$ & $4,100,1000$ & $64,601,680$ & $2,460,000$ & 300,000 & $61.845,600$ & $19,8000,000$ & $42,045,680$ & \\
\hline ggus & $\mathrm{K} / 3$ & 4.218 .200 & $2,1750,000$ & $46,968.200$ & $1,650,000$ & 300,000 & $45,018.200$ & $21,120,000$ & 238989.200 & \\
\hline Heri & TKN/0 & H.218.200 & 2.750,000 & $40,968.200$ & $1,650,000$ & 300,000 & $45,018,200$ & 15.840,000 & $29,178.200$ & \\
\hline Mimi & TIKI0 & $39,993,520$ & $2,400,000$ & $42,393,520$ & $1,40,000$ & 300,000 & $40,653.520$ & $15,800,000$ & 24.815 .520 & \\
\hline Eko & K/2 & H.218.200 & $2,750,0000$ & $40,968.200$ & $1,650,000$ & 300,000 & $45,018,200$ & 19,800,000 & 25.218 .200 & 1.261 \\
\hline Suriati & TKNO & $30,833,840$ & $3,300,000$ & 34.153 .840 & $1,980,000$ & 300,000 & 51.873 .840 & $15.840,000$ & $36,033.840$ & 1.80 \\
\hline Sutrisno & $\mathrm{K} / 3$ & $60,0,0,6,600$ & $4,100,1000$ & $64,603,680$ & $2,460,000$ & 300,000 & $61.845,680$ & $21.120,000$ & $40,725,6800$ & 20,35 \\
\hline Samsul & $\mathrm{K} / 2$ & $71,36+1,000$ & $5,000,000$ & $76,364,000$ & $3,000,000$ & 300,000 & $73,064,000$ & $19,800,000$ & $33.64,000$ & 2988 \\
\hline Iri & $\mathrm{K} / 3$ & H.1218.200 & 2,150,0000 & 46.968 .200 & $1,650,000$ & 300,000 & $45,018,2000$ & $21.120,000$ & 23998,200 & \\
\hline Yono & K/3 & H.218.200 & $2,170,000$ & $46,968.200$ & $1,650,000$ & 300,000 & $45,018,2000$ & $21.120,000$ & 23898,200 & \\
\hline putria & K/2 & H.128.200 & $2,750,0000$ & $40,968.200$ & $1,650,000$ & 300,000 & $45,018,200$ & $19,800,000$ & 25.218.200 & 1.260. \\
\hline TOTAL & & $1.388 .970,720$ & $1001,400,000$ & $1,490,370,720$ & $45.240,000$ & $4,000,000$ & $1,40 ., 630,7200$ & 211,720,000 & $1,148,910,720$ & 00 \\
\hline
\end{tabular}

Penerapan Perhitungan PPh Pasal 21 dengan Metode Net Terhadap

\section{PPh Badan}

a. Berikut ini adalah penerapanperhitunganPPh Pasal 21 dengan Metode Net dan pengaruhnya terhadap PPh Badan PT. Citra Damai Putra tahun 2010: 
Tabel 4.4

Rekonsiliasi Fiskal

Tahun 2010

\begin{tabular}{|c|c|c|c|c|}
\hline \multirow[t]{2}{*}{ Keterangan } & \multicolumn{3}{|c|}{ Koreksi Fiskal } & \multirow[b]{2}{*}{ Koreksi Fiskal } \\
\hline & Komersial & positif & Negatif & \\
\hline \multicolumn{5}{|l|}{ Pendapatan } \\
\hline Penjualan & 8.974 .554 .600 & & & 8.974 .554 .600 \\
\hline Harga pokok Peniualan & 1.122 .760 .500 & & & 1.122 .760 .500 \\
\hline Total Pendapatan Usaha & 7.851 .794 .100 & & & 7.851 .794 .100 \\
\hline \multicolumn{5}{|l|}{ Biaya Umum dan Administrasi } \\
\hline Biaya Gaji Karyawan dan THR & 1.074 .910 .080 & & & 1.074 .910 .080 \\
\hline Biaya PPh Pasal 21 & 64.646 .184 & & & 64.646 .184 \\
\hline Biaya Listrik dan Pam & 3.089 .612 & & & 3.089 .612 \\
\hline Biaya Pengobatan ditnggung Perusahaan & 20.000 .000 & 20.000 .000 & & 0 \\
\hline Cadangan Penghappusan piutang & 5.000 .000 & 5.000 .000 & & 0 \\
\hline Biaya Tol, Bensin dan Parkir & 50.969 .125 & & & 50.969 .125 \\
\hline Sanksi Adm Pajak & 10.000 .000 & 10.000 .000 & & 0 \\
\hline Biaya Pengiriminan TIKI & 302.000 & & & 302,000 \\
\hline Biaya Telpn dan Fax & 8.966 .000 & & & 8.966 .000 \\
\hline Biaya Handphone & 40.685 .455 & & & 40.685 .455 \\
\hline Biaya Internet & 3.250 .100 & & & 3.250 .100 \\
\hline Biaya Entertainment, Iuran, Sumbangan & 25.615 .200 & & & 25.615 .200 \\
\hline Biaya Penyusutan Inventaris Kantor & 1.325 .000 & & & 1.325 .000 \\
\hline Biaya Penyusutan Mesin dan Peralatan & 550.000 & & & 550.000 \\
\hline Biaya Amortisasi biaya Pra Opernsi & 100.000 & & & 100.000 \\
\hline Biaya Penyusutan Inventaris Kendaraan & 3.800 .150 & & & 3.800 .150 \\
\hline Total Biaya Umum \& Administrasi & 1.313 .208 .906 & 35.000 .000 & & 1.278 .208 .906 \\
\hline Penghasilan neto dari usaha & 6.538 .585 .194 & 35.000 .000 & & 6.573 .585 .194 \\
\hline \multicolumn{5}{|l|}{ Pendapatan Non Usaha } \\
\hline Deviden dari PT. Duia Bumai & 85.000 .000 & 15.000 .000 & & 100.000 .000 \\
\hline Jasa Giro Bank Mandiri & 2.000 .000 & & 2.000 .000 & 0 \\
\hline Jumlah Pendapatan Non Usaha & 87.000 .000 & 15.000 .000 & 2.000 .000 & 100.000 .000 \\
\hline Biaya diluar usaha & 0,00 & & & \\
\hline Laba Sebelum Pajak & $6.625 .585 .194,00$ & 50.000 .000 & 2.000 .000 & 6.673 .585 .194 \\
\hline
\end{tabular}

Sumber : PT. Citra Damai Putra

1. Peredaran Usaha

Laba Sebelum Pajak

Koreksi Positif

Pajak Ditanggung Perusahan

Dasar Pengenaan Pajak (DPP)

Pembulatan DPP
: 7.851.794.100

: 6.625.585.194

: 50.000 .000

: $\underline{64.646 .184}(+)$

: 6.740.231.378

: 6.740.231.000

2. PPh Terutang

a. Bagian penghasilan kena pajak atau dasar pengenaan pajak yang memperoleh fasilitas adalah sebesar (Rp4.800.000.000/Rp7.851.794.100)xRp6.740.231.000 $=$ Rp 4.120.473.409.- 


$$
\begin{aligned}
\mathrm{PPh} \text { terutang } & =50 \% \times 25 \% \times \mathrm{Rp} 4.120 .473 .409 \\
& =\mathrm{Rp} 515.059 .176 .-
\end{aligned}
$$

b. Bagian penghasilan kena pajak atau dasar pengenaan pajak yang tidak memperoleh fasilitas adalah sebesar (Rp 6.740.231.000-Rp 4.120.473.409) =Rp 2.619.757.591;

PPh Terutang sebesar 25\% x Rp 2.619.757.591

$=\operatorname{Rp} 654.939 .398$

c. Total PPh terutang Rp515.059.176+Rp 654.939.398

$=\operatorname{Rp} 1.169 .998 .574$

Berikut ini adalah penerapan perhitunganPPh Pasal 21 dengan Metode Net dan pengaruhnya terhadap PPh Badan PT. Citra Damai Putra tahun 2011.

Tabel 4.5

Rekonsiliasi Fiskal

\begin{tabular}{|c|c|c|c|c|}
\hline \multirow[t]{2}{*}{ Koiseranzen } & \multicolumn{3}{|c|}{ Korolesi Finkzl } & \multirow[b]{2}{*}{ Korolesi Fialal } \\
\hline & Komorgizl & oosisif & Nonziff & \\
\hline \multicolumn{5}{|l|}{ Pondepatan } \\
\hline Poniaglen & 9.794 .655 .200 & & & 9.794 .665 .200 \\
\hline Haraz oolvol Ponjualen & 1352750550 & & & 1352750550 \\
\hline Total Pondzoztan Uszhs & 8.431 .914 .650 & & & 8.431 .914 .680 \\
\hline \multicolumn{5}{|l|}{ Biava Unum dan Administray } \\
\hline Bizyz Gaij Karyzwen den THR. & 1.802 .672 .658 & & & 1. 30267265 \\
\hline Bazyz PPh Pasal 21 & 93.962 .034 & & & 93.962034 \\
\hline Bazyz Lastric den Pam & 4527.365 & & & 4327365 \\
\hline Bizyz Ponzobatan ditnzesen Persuzhe & 25.000 .000 & 23.000 .000 & & 0 \\
\hline Cadencen Ponchroprasn pistens & 7.000 .000 & 7.000 .000 & & 0 \\
\hline Biayz Tol Bondin den Parkir & 35.735 .794 & & & 35.735 .794 \\
\hline Szoniou Adm Paiz: & 12000.000 & 12000.000 & & 0 \\
\hline Bazyz Pongiriminzen TIKI & 320.000 & & & 320.000 \\
\hline Bizyz Tolon den Fax & 10974243 & & & 10974243 \\
\hline Bazya Handohoes & 50.153 .315 & & & 50.155 .315 \\
\hline Bizyz Internet & 3972573 & & & 3972573 \\
\hline 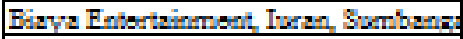 & 30.250 .400 & & & 30.250 .400 \\
\hline Bazyz Peayoustan Inventaris Kantor & 2500.000 & & & 2500.000 \\
\hline Bazyz Poayourtan Mosin den Porzlata & 750.000 & & & 750.000 \\
\hline Bizyz Amortisud bizvz Pra Oporasi & $\$ 00.000$ & & & $\$ 00.000$ \\
\hline Bazyz Ponyoustan Inventaris Kondera & 5.075 .000 & & & 5.075 .000 \\
\hline Total Binva Unerm \& Admisistrsai & 1.605 .495 .672 & 44.000 .000 & & 1.561 .495 .672 \\
\hline Pergbasilan noto dari cuaba & 6.826 .418 .978 & 44.000 .000 & & 6.870 .418 .978 \\
\hline \multicolumn{5}{|l|}{ Perdapatan Non Usaba } \\
\hline Deriden deri PT. Dota Benti & 90.000 .000 & 20.000 .000 & & 110.000000 \\
\hline Iasa Giro Benk Mandiri & 3500.000 & & 3.500 .0001 & 0 \\
\hline Jemlab Peadapatan Non Uraba & 93.500 .000 & 20.000 .000 & 3.500 .000 & 110.000 .000 \\
\hline Biayz dilozer washa & 0.00 & & & 0 \\
\hline Laba Sobelem Pajal & $6919,918978,00$ & 64.000 .000 & 3.500 .000 & 6990.418978 \\
\hline
\end{tabular}

Tahun 2011

Sumber : PT. Citra Damai Putra 
3. Peredaran Usaha

: 8.431.914.650

Laba Sebelum Pajak

: 6.919.915.978

Koreksi Positif

: 64.000 .000

Pajak Ditanggung Perusahan

: $\underline{95.562 .034}(+)$

Dasar Pengenaan Pajak (DPP)

: 7.079.478.012

Pembulatan DPP

: 7.079.478.000

4. PPh Terutang

a. Bagian penghasilan kena pajak atau dasar pengenaan pajakyang memperoleh fasilitas adalah sebesar (Rp4.800.000.000/Rp8.431.914.650)xRp7.079.478.000 $=\operatorname{Rp} 4.030 .104 .171 .-$

$\mathrm{PPh}$ terutang $=50 \% \times 25 \% \times \mathrm{Rp} 4.030 .104 .171$

$$
=\operatorname{Rp} 503.763 .021 .-
$$

b. Bagian penghasilan kena pajak atau dasar pengenaan pajak yang tidak memperoleh fasilitas adalah sebesar (Rp 7.079.478.000-Rp 4.030.104.171) =Rp 3.049.373.829;

PPh Terutang sebesar 25\% x Rp3.049.373.829

$=\operatorname{Rp} 762.343 .457$

c. Total PPh terutang Rp503.763.021+Rp762.343.457

$=\operatorname{Rp} 1.266 .106 .478$

Berikut ini adalah penerapan perhitunganPPh Pasal 21 dengan Metode Net dan pengaruhnya terhadap PPh Badan PT. Citra Damai Putra tahun 2012: 
Tabel 4.6

Rekonsiliasi Fiskal

Tahun 2012

\begin{tabular}{|c|c|c|c|c|}
\hline \multirow[t]{2}{*}{ Koteranzan } & \multicolumn{2}{|c|}{ Korolesi Falcal } & \multirow[b]{2}{*}{ Nonzif } & \multirow[b]{2}{*}{ Korolesi Fialcal } \\
\hline & Konmersiz! & pogitif & & \\
\hline \multicolumn{5}{|l|}{ Pondepaten } \\
\hline Ponizalen & 10.594 .400300 & & & 10.554400 .300 \\
\hline Haraz poloot: Poniualen & 1.432454255 & & & 1.432454 .255 \\
\hline Total Peodepatan Uasha & 9.451 .945 .045 & & & 9.451 .945 .045 \\
\hline \multicolumn{5}{|l|}{ Biava Uimrm dan Administrani } \\
\hline Biayza Gaji Karyzmen den THR & 1. $=90.270 .720$ & & & 1. 1900.770 .730 \\
\hline Biayz PPh Pasal 21 & 119943.176 & & & 119943.176 \\
\hline 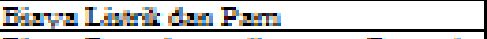 & 63.49 .405 & & & 6349.405 \\
\hline Bizyz Penaobztzen dimnzeseng Persazhn & 28.000 .000 & 28.000 .000 & & 0 \\
\hline Codenzen Pengheporazn pirsteng & 10.000 .000 & 10.000000 & & 0 \\
\hline Biayza Tol Bonain den Parkir & 61.356 .117 & & & 61.356 .117 \\
\hline Senikei Adm Paizle & 14.000 .000 & 14.000000 & & 0 \\
\hline Bazyz Pongiriminzen TIKI & 650.000 & & 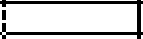 & 650.000 \\
\hline Biayra Tolon den Fax & 12549.163 & & 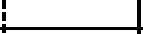 & 12549.163 \\
\hline Biayz Handohoes & 60.525 .413 & & 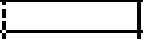 & 60.525 .413 \\
\hline Bizyza Internes! & 4.453 .992 & & & 4.453 .992 \\
\hline Bizyz Entertzinment. Ivaren, Sumbena: & 35995.700 & & & 35995.700 \\
\hline Bizyz Penposutan Invontzris Kantor & 2570500 & & & 2570500 \\
\hline Bizyz Ponyoustan Mosin den Peralatz: & 1.000 .000 & & & 1.000 .000 \\
\hline Bizyz Anoertinzai bizyza Prz Oporzai & 350.000 & & & 350.000 \\
\hline Bizyz Pearyouten Invonteris Konderz & 35.69 .000 & & & 3569.000 \\
\hline Total Biava Umem \& Administrani & 1.857 .521 .185 & 52.000 .000 & & 1.805521 .185 \\
\hline Pespbanilan neto dari waba & 7.594 .424 .559 & $52.000 .000^{i}$ & & 7.645 .424 .859 \\
\hline \multicolumn{5}{|l|}{ Peodaparan Non Usaba } \\
\hline Deriden deri PT. Deta Brami & 100000000 & $25.000000 i$ & & 125.000000 \\
\hline Inaz Giro Bant Mlandiri & 5.000 .000 & & 5.000000 & \\
\hline Jemlab Peadapatan Non Uxaba & 105.000 .000 & $25.000000 i$ & 5.000 .000 & $125,000,000$ \\
\hline Bizyz dihser wahn & 0,00 & & 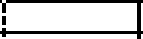 & 0 \\
\hline Laba Sobelem Pajak & $7.699 .424 .859,00$ & $77.000 .000 i$ & 5.000 .000 & 7.771 .424 .859 \\
\hline
\end{tabular}

Sumber : PT. Citra Damai Putra

5. Peredaran Usaha

: 9.451 .946 .045

Laba Sebelum Pajak

: 7.699 .424 .859

Koreksi Positif

: 77.000 .000

Pajak Ditanggung Perusahan

: $119.945 .176(+)$

Dasar Pengenaan Pajak (DPP)

: 7.896.370.035

Pembulatan DPP

: 7.896.370.000

6. PPh Terutang

a. Bagian penghasilan kena pajak atau dasar pengenaan pajak yang memperoleh fasilitas adalah sebesar

$$
\begin{aligned}
& (\mathrm{Rp} 4.800 .000 .000 / \mathrm{Rp} 9.451 .946 .045) \times R p 7.896 .370 .000 \\
& =\mathrm{Rp} 4.010 .028 .815 .- \\
& \mathrm{PPh} \text { terutang }=50 \% \text { × } 25 \% \text { × } \mathrm{Rp} 4.010 .028 .815
\end{aligned}
$$


$=\operatorname{Rp} 501.253 .602 .-$

b. Bagian penghasilan kena pajak atau dasar pengenaan pajak yang tidak memperoleh fasilitas adalah sebesar (Rp 7.896.370.000-Rp 4.010.028.815) =Rp 3.886.341.185;

$\mathrm{PPh}$ Terutang sebesar 25\% x Rp 3.886.341.185

$=\operatorname{Rp} 971.585 .296$

c. Total PPh terutang Rp501.253.602+Rp 971.585.296

$=\operatorname{Rp} 1.472 .838 .898$

\section{Penerapan Perhitungan PPh Pasal 21 Dengan Metode Gross Up}

Untuk menetukan besarnya tunjangan pajak dengan metode Gross $U p$ dapat digunakan rumus yaitu sebagai berikut.

\section{Rumus Gross Up}

Perhitungan Tunjangan PPh Pasal 21

\begin{tabular}{|c|c|c|}
\hline Lapisan I & PKP 0 s/d 47.500.000 & (PKP - 0) x 5/95 + 0 \\
\hline \multirow{2}{*}{ Lapisan II } & PKP 47.500.000 - & (PKP - 47.500.000) x 15/85 + \\
\hline & 217.500 .000 & 2.500 .000 \\
Lapisan III & 405.000 .000 & $($ PKP - 217.500.000) x 25/75 \\
\hline & & +32.500 .000 \\
Lapisan IV & PKP diatas 405.000.000 & +95.000 .000 \\
\hline
\end{tabular}

Sumber : Cara siasati pajak

Berikut ini adalah contoh perhitungan PPh Pasal 21 Terutang dengan metode gross upsalah satu karyawan perusahaan pada tahun 2010,atas nama Amir jabatan Directur status kawin mempunyai 2 orang anak telah memiliki NPWP bekerja pada PT. Citra Damai Putra dengan memperoleh gaji sebesar Rp 120.000.000,00 setahun. Berdasarkan perhitungan PKP setahun sebelum tunjangan pajak yang telah diketahui adalah sebesar Rp 104.548.000 dengan biaya jabatan setahun Rp6.000.000 dan PKP setahun diatas Rp 50.000.000 maka formula yang digunakan adalah : 
Tunjangan Pajak PPh Pasal 21

$$
\begin{aligned}
& =\frac{(\mathrm{PKP}-\mathrm{Rp} 47.500 .000) \times 15 \%+\mathrm{Rp} \mathrm{2.500.000}}{0,85} \\
& =\frac{(\operatorname{Rp} 115.588 .000-\mathrm{Rp} 47.500 .000) \times 15 \%+\mathrm{Rp} 2.500 .000}{0,85} \\
& =\operatorname{Rp} 14.515 .529
\end{aligned}
$$

Dari perhitungan diatas didapat tunjangan pajak sebesar Rp $13.297 .882,00$

Gaji sebulan

Rp 120.000.000,00

Tunjangan Makan

Rp 7.200.000,00

Tunjangan kesehatan

Rp $\quad 3.600 .000,00$

Tunjangan Pajak

Rp 14.515.529,00

Uang Lembur

Rp 240.000,00

THR

Rp 10.000.000,00

JKK 0,24\% x Rp 120.000.000

Rp 288.000,00

JKM 0,3\% x Rp 120.000.000

Rp $\quad 360.000,00$

Penghasilan Bruto

Rp 156.203.529,00

Pengurang:

Biaya jabatan setahun:

$5 \%$ x Rp 156.203.529= Rp 6.000.000,00

Iuran Pensiun setahun $\quad$ Rp $300.000,00$

$\underline{\operatorname{Rp} 6.300 .000,00}$

Penghasian Neto setahun

Rp 149.903.529,00

PTKP $(K / 2)$ setahun

Untuk WP sendiri $\quad$ Rp 15.840.000,00

Tambahan WP kawin $\quad$ Rp 1.320.000,00

Tambahan 2 orang anak $\quad \underline{\operatorname{Rp} 2.640 .000,00}$

$\underline{\mathrm{Rp} 19.800 .000,00}$

Penghasilan Kena Pajak setahun

Rp 130.103.529,00

PPh Pasal 21 Terutang 


$$
\begin{array}{ll}
5 \% \times \operatorname{Rp} 50.000 .000 & =\operatorname{Rp} 2.500 .000 \\
15 \% \times \operatorname{Rp~80.103.529~} & =\underline{\operatorname{Rp} 12.015 .529}
\end{array}
$$

$$
\text { Rp 14.515.529 }
$$

Jadi dengan diterapkan metode gross up dalam perhitungan PPh Pasal21 terutang, maka penghasilan bruto karyawan menjadi $\mathrm{Rp}$ 156.203.529,00dengan tunjangan pajak Rp 14.515.529,00. Sehingga jumlah PPh Pasal 21 terutang yang ditanggung perusahaan dengan metode gross up sebesar Rp 14.515.529,00 yang jumlahnya sama besar dengan jumlah tunjangan pajak yang diberikan perusahaan kepada karyawan tetap.

Berikut ini disajikan Tabel 4.4 Untuk tahun 2010, Tabel 4.5 Untuk tahun 2011, Tabel 4.6 Untuk tahun 2012 mengenai total penghasilan PPh Pasal 21 terutang yang ditanggung perusahaan dengan menggunakan metode gross up terhadap 15 karyawan tetap yang diterapkan PT. Citra Damai Putra, sebagai berikut :

Tabel 4.7

\begin{tabular}{|c|c|c|c|c|c|c|c|c|c|c|}
\hline \multirow{2}{*}{\begin{tabular}{|c|} 
Nama \\
Karyawan
\end{tabular}} & \multirow{2}{*}{$\begin{array}{c}\text { Gaji } \\
\text { Setahun }\end{array}$} & \multirow{2}{*}{$\begin{array}{c}\text { Tunjangan } \\
\text { pajak }\end{array}$} & \multirow[t]{2}{*}{ THR } & \multirow{2}{*}{$\begin{array}{l}\text { penghasilan } \\
\text { Bruto Setahun }\end{array}$} & \multicolumn{2}{|c|}{ Pengurangan } & \multirow{2}{*}{$\begin{array}{l}\text { Penghasilan } \\
\text { Neto Setahun }\end{array}$} & \multirow{2}{*}{$\begin{array}{l}\text { PTKP } \\
\text { Setahun }\end{array}$} & \multirow[t]{2}{*}{ PKP } & \multirow{2}{*}{$\begin{array}{l}\text { PPh } 21 \\
\text { Sctahun }\end{array}$} \\
\hline & & & & & B. Jabatan & luran & & & & \\
\hline Amir & 131.688.000 & 14.515 .529 & 10.000 .000 & 156.203 .529 & 6.000 .000 & 300,000 & 149.903 .529 & 19.800 .000 & 130.103 .529 & 14.515 .529 \\
\hline Abbas & 192.012 .000 & 25.810 .353 & 15.000 .000 & 232.822 .353 & 6.000 .000 & 300,000 & 226.522 .353 & $21.120,000$ & 205.402 .353 & 25.810 .353 \\
\hline Budi & 107.558 .400 & 10.116 .188 & 8.000 .000 & 125.674 .588 & 4.800 .000 & 300,000 & 120.574 .588 & 19.800 .000 & 100.774 .588 & 10.116 .188 \\
\hline$\overline{K i k i}$ & 107.558 .400 & 10.116 .188 & 8.000 .000 & 125.674 .588 & 4.800 .000 & 300,000 & 120.574 .588 & 19.800 .000 & 100.774 .588 & 10.116 .188 \\
\hline Ridwan & 50.853 .840 & 1.688 .097 & 3.300 .000 & 55.841 .937 & 1.980 .000 & 300,000 & 53.561 .937 & 19.800 .000 & 33.761 .937 & 1.688 .097 \\
\hline Agus & 37.582 .560 & 896.977 & 2.200 .000 & 40.679 .537 & 1.320 .000 & 300,000 & 39.059 .537 & 21.120 .000 & |7.939.537 & 896.977 \\
\hline Heri & 37.582 .560 & 1.174 .872 & 2.200 .000 & 40.957 .432 & 1.320 .000 & 300.000 & 39.337 .432 & 15.840 .000 & 23.497 .432 & 1.174 .872 \\
\hline Mimi & 37.582 .560 & 1.174 .872 & 2.200 .000 & 40.957 .432 & 1.320 .000 & 300,000 & 39.337 .432 & 15.840 .000 & 23.497 .432 & 1.174 .872 \\
\hline Eko & 37.582 .560 & 966.451 & 2.200 .000 & 40.749 .011 & 1.320 .000 & 300.000 & 39.129 .011 & 19.800 .000 & 19.329 .011 & 966.451 \\
\hline Suriati & 44.218 .200 & 1.535 .695 & 2.750 .000 & 48.503 .895 & 1.650 .000 & 300.000 & 46.553 .895 & 15.840 .000 & 30.713 .895 & 1.535 .695 \\
\hline Sutrisno & 50.853 .840 & 1.618 .623 & 3.300 .000 & 55.772 .463 & 1.980 .000 & 300,000 & 53.492 .463 & 21.120 .000 & 32.372 .463 & 1.618 .623 \\
\hline Samsul & 57.489 .480 & 2.048 .920 & 3.850 .000 & 63.388 .400 & 2.310 .000 & 300,000 & 60.778 .400 & 19.800 .000 & 40.978 .400 & 2.048 .920 \\
\hline Tri & 37.582 .560 & 896.977 & 2.200 .000 & 40.679 .537 & 1.320 .000 & 300,000 & 39.059 .537 & 21.120 .000 & 17.939 .537 & 896.977 \\
\hline yono & 37.582 .560 & 896.977 & 2.200 .000 & 40.679 .537 & 1.320 .000 & 300,000 & 39.059 .537 & $21.120,000$ & 17.939 .537 & 896.977 \\
\hline putra & 37.582 .560 & 966.451 & $2.200,000$ & $40,749.011$ & 1.320 .000 & 300,000 & 39.129 .011 & $19.800,000$ & 19.329 .011 & 966.451 \\
\hline TOTAL & 1.005 .310 .080 & 74.423 .168 & 69.600 .000 & 1.149 .333 .248 & 38.760 .000 & 4.500 .000 & 1.106 .073 .248 & 291.720 .000 & 814.353 .248 & 74.423 .168 \\
\hline
\end{tabular}

Perhitungan PPh 21 Tahun 2010

Dengan Metode Gross Up 
Tabel 4.8

Perhitungan PPh 21 Tahun 2011

Dengan Metode Gross Up

\begin{tabular}{|c|c|c|c|c|c|c|c|c|c|c|}
\hline \multirow{2}{*}{$\begin{array}{c}\text { Nama } \\
\text { Karyawan } \\
\end{array}$} & \multirow{2}{*}{$\begin{array}{c}\text { Gaji } \\
\text { Setahun }\end{array}$} & \multirow{2}{*}{$\begin{array}{c}\text { Tunjangan } \\
\text { Pajak } \\
\end{array}$} & \multirow[t]{2}{*}{ THR } & \multirow{2}{*}{$\begin{array}{l}\text { penghasilan } \\
\text { Bruto Setahun }\end{array}$} & \multicolumn{2}{|c|}{ Pengurangan } & \multirow{2}{*}{$\begin{array}{l}\text { Penghasilan } \\
\text { Neto Setahun } \\
\end{array}$} & \multirow{2}{*}{$\begin{array}{c}\text { PTKP } \\
\text { Setahun } \\
\end{array}$} & \multirow[t]{2}{*}{ PKP } & \multirow{2}{*}{$\begin{array}{l}\text { PPh 2I } \\
\text { Setahun } \\
\end{array}$} \\
\hline & & & & & B. Jabatan & luran & & & & \\
\hline Amir & 192.012 .000 & 26.043 .294 & 15.000 .000 & 233.055 .294 & $6.000,000$ & 300.000 & 226.755 .294 & 19.800 .000 & 206.955 .294 & 26.043 .29 \\
\hline bbas & 252.336 .000 & 41.638 .667 & 20.000 .000 & 313.974 .667 & 6.000 .000 & 300.000 & 307.674 .667 & 21.120 .000 & 286.554 .667 & 41.638 .667 \\
\hline Sudi & 131.688 .000 & 14.515 .529 & 10.000 .000 & 156.203 .529 & 6.000 .000 & 300.000 & 149.903 .529 & 19.800 .000 & 130.103 .529 & 14.515 .529 \\
\hline Kiki & 131.688 .000 & 14.515 .529 & 10.000 .000 & 156.203 .529 & 6.000 .000 & 300.000 & 149.903 .529 & 19.800 .000 & 130.103 .529 & 14.515 .529 \\
\hline Ridwan & 55.679 .760 & 1.950 .514 & 3.700 .000 & 61.330.274 & 2.220 .000 & 300.000 & 58.810 .274 & 19.800 .000 & 39.010 .274 & \\
\hline Agus & 41.202 .000 & 1.093 .789 & 2.500 .000 & 44.795 .789 & 1.500 .000 & 300.000 & 42.995 .789 & 21.120 .000 & 21.875 .789 & \\
\hline Heri & 41.202 .000 & 1.371 .684 & 2.500 .000 & 45.073 .684 & $1.500,000$ & 300.000 & 43.273 .684 & 15.840 .000 & 27.433 .684 & \\
\hline Mimi & 39.794 .038 & 1.295 .124 & 2.383 .300 & 43.472 .462 & 1.429 .980 & 300.000 & 41.742 .482 & 15.840 .000 & 25.902 .482 & \\
\hline Eko & 41.202 .000 & 1.163 .263 & 2.500 .000 & 44.865 .263 & 1.500 .000 & 300.000 & 43.065 .263 & 19.800 .000 & 23.265 .263 & \\
\hline Suriati & 47.234 .400 & 1.699 .705 & 3.000 .000 & 51.934 .105 & 1.800 .000 & 300.000 & 49.834 .105 & 15.840 .000 & 33.994 .105 & 1.699 .70 \\
\hline Sutrisno & 55.679 .760 & 1.881 .040 & 3.700 .000 & 61.260 .800 & 2.220 .000 & 300.000 & 58.740 .800 & 21.120 .000 & 37.620 .800 & 1.881 .040 \\
\hline Samsul & 62315,400 & 2.311 .337 & 4.250 .000 & 68.876 .737 & 2.550 .000 & 300.000 & 66.026 .737 & 19.800 .000 & 46.226 .737 & 2.311 .337 \\
\hline Tri & 41.202 .000 & 1.093 .789 & 2.500 .000 & 44.795 .789 & 1.500 .000 & 300.000 & 42.995 .789 & 21.120 .000 & 21.875 .789 & 1.093 .789 \\
\hline yono & 41.202 .000 & 1.093 .789 & 2.500 .000 & 44.795 .789 & 1.500 .000 & 300.000 & 42.995 .789 & 21.120 .000 & 21.875 .789 & 1.093 .789 \\
\hline putra & 41.202 .000 & 1.163 .263 & 2.500 .000 & 44.865 .263 & 1.500 .000 & 300.000 & 43.065 .263 & 19.800 .000 & 23.265 .263 & 1.163 .263 \\
\hline TOTAL & 1.215 .639 .358 & 112.830 .318 & $87,033,300$ & 1.415 .502 .976 & 43.219 .980 & 4.500 .000 & 1.367 .782 .996 & 291.720 .000 & 1.076 .062 .996 & \\
\hline
\end{tabular}

Tabel 4.9

Perhitungan PPh 21 Tahun 2012

Dengan Metode Gross Up

\begin{tabular}{|c|c|c|c|c|c|c|c|c|c|c|}
\hline \multirow{2}{*}{\begin{tabular}{|c} 
Nama \\
Karyaxan
\end{tabular}} & \multirow{2}{*}{$\begin{array}{l}\text { Gajil } \\
\text { Setahun }\end{array}$} & \multirow{2}{*}{$\begin{array}{l}\text { Tunjangan } \\
\text { Pajajk }\end{array}$} & \multirow[t]{2}{*}{ THR } & \multirow{2}{*}{ 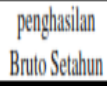 } & \multicolumn{2}{|c|}{ Pengurangan } & \multirow{2}{*}{$\begin{array}{l}\text { Penghasilan } \\
\text { Neto Setahun }\end{array}$} & \multirow{2}{*}{$\begin{array}{l}\text { PTKP } \\
\text { Sethan }\end{array}$} & \multirow[t]{2}{*}{ PKP } & \multirow{2}{*}{$\begin{array}{l}\text { PPh 2l } \\
\text { Setahun }\end{array}$} \\
\hline & & & & & B. Jabatan & luran & & & & \\
\hline Amir & 2523366000 & 420.78 .660 & $20,000.000$ & $314,414.667$ & 6.000 .000 & 300.000 & 308.114 .6607 & $19,800.00$ & 2888.314667 & 42078.66 \\
\hline bbas & 276.465 .600 & 50.348 .52 & $22,000.000$ & 348.814 .133 & 6.000 .000 & 300,000 & 3425.54 .13 & 21.120 .000 & 321.394 .13$. & 50.348 .53 \\
\hline udi & 155.817 .600 & 19,126.63. & $12,000,000$ & $186.94,235$ & 6.000 .000 & 300,000 & 180.644 .23$. & 19.800.000 & 1600.844 .23$. & 19.126.6. \\
\hline Kiki & 155.877 .600 & 19,126.63. & $12,000,000$ & 186.944 .235 & 6.000 .000 & 300,000 & 180.644 .235 & 19.8000 .00 & 1600.844 .23$. & 19.126.6. \\
\hline$\overline{\text { Ridwan }}$ & 60.505 .680 & 2212.93 & $4,1000,000$ & 66.818 .6111 & $2,460,000$ & 300,000 & 64.058 .611 & $19,800.000$ & 44.258 .611 & 2.12 .95 \\
\hline Agus & 4.218 .200 & 1.257 .800 & 27500.000 & 48.226 .000 & $1.650,000$ & 300,000 & 46.276 .000 & 21.120 .000 & 251566000 & 1.257 .80 \\
\hline Heri & 4.218 .200 & 15356.695 & 2750.000 & 485030.895. & 1.650 .000 & 300,000 & 46.553 .895 & 15.8000 .00 & 30.7133895 & 15356.69 \\
\hline Mimi & 399955.520 & $1,306,080$ & 2400.000 & 437701.600 & 1.400 .000 & 300,000 & 41.961 .600 & 15.840 .000 & 26.121 .600 & $1,306.08$ \\
\hline Eklo & 4.218 .200 & $1,327.274$ & 2750.000 & 48.259 .474 & 1.650 .000 & 300,000 & 46.345 .474 & $19,800.00$ & 26.545 .474 & 1.327 .27 \\
\hline Suriati & 50.853 .840 & 1.896 .518 & 33000000 & 56.5050 .358 & 1.980000 & 300,000 & 53.770 .358 & 15.840 .000 & 3793030.358 & 1.896 .515 \\
\hline Sutrisso & 60.550 .680 & $2.143,457$ & 4.100 .000 & $66.74,137$ & 2460,000 & 300,000 & 639899.137 & 21.120 .000 & $42.869,137$ & $2.143,45$ \\
\hline Samsul| & $71,364,000$ & 3.517 .176 & 5000000 & 79.881 .176 & 3000,000 & 300,000 & 76.5881 .176 & $19,800,000$ & 56.781 .176 & 3.517 .17 \\
\hline Th & 44.218 .2200 & 1.257 .800 & 2750.000 & 48.26 .000 & 1.650 .000 & 300,000 & 462.276 .000 & 21.120 .000 & 251566.000 & 1.257 .80 \\
\hline ono & 44.218 .200 & 1.257 .800 & 2750.000 & 48.226 .000 & $1.650,000$ & 300,000 & 46.276 .000 & 21.120 .000 & 255.156 .000 & 1.257 .80 \\
\hline ala & 44.218 .2200 & 1.327 .274 & 2750.000 & 48.255 .774 & $1.650,000$ & 300,000 & 46.345 .774 & $19,800,000$ & 265.545 .774 & 1327.27 \\
\hline TOTAL & 1.3889700720 & $149,720.274$ & $101,400,000$ & 1.640 .090 .094 & 45.440 .000 & 4.500 .000 & 590.350 .994 & $291,720.000$ & $298,630.994$ & $149,720.27$ \\
\hline
\end{tabular}




\section{Penerapan Perhitungan PPh Pasal 21 dengan Metode Gross Up Terhadap PPh Badan}

a. Berikut ini adalah penerapan perhitunganPPh Pasal 21 dengan Metode Gross Up dan pengaruhnya terhadap PPh Badan PT. Citra Damai Putra tahun 2010:

Tabel 4.10

Rekonsiliasi Fiskal

Tahun 2010

\begin{tabular}{|c|c|c|c|c|}
\hline \multirow[t]{2}{*}{ Koterankza } & \multicolumn{3}{|c|}{ Korgiced Fatcal } & \multirow[b]{2}{*}{ Korotoi Fintal } \\
\hline & Komperaizl & popistif & Nozasif & \\
\hline \multicolumn{5}{|l|}{ Pondzozizen } \\
\hline Ponjualen & 3974.554 .600 & & & 3974.554 .600 \\
\hline Hzerza pologk Peniwalen & 1.122760 .500 & & & 1.122760 .500 \\
\hline Total Pondepatzen Uashn & 7.351 .794 .100 & & & 7.351 .794 .100 \\
\hline \multicolumn{5}{|l|}{ Biava Umem dan Administravi } \\
\hline Bazyz Gaij Karyzaren den THR. & 1. 0ne.910.000 & & & 1.074.910.008 \\
\hline Traiznasn Paizk & 74.423 .163 & & & 74.423 .165 \\
\hline Bazyz Lastriz den Pam & 3.059 .612 & & & 3.059 .612 \\
\hline Bizyz Ponaobatzen dinnexpena Peruazhren & 20.000 .000 & 20.000 .000 & & 0 \\
\hline Codencen Ponghroposazen pirotzeng & 5.000 .000 & 5.000 .000 & & 0 \\
\hline Bizya Tol Bongin den Parkir & 50969.125 & & & 50969.125 \\
\hline Sankoi Adm Paials & 10.000 .000 & 10.000 .000 & & 0 \\
\hline Bazyz Pongiriminge TIKI & 302000 & & & 302000 \\
\hline Bazya Tolon den Fax & 3965,000 & & & 3.956 .000 \\
\hline Bizyz Hzendohone & 40.655 .453 & & & 40.655 .455 \\
\hline Bizyza Internet & 3.250 .100 & & & 3.250 .100 \\
\hline Bizyza Entertzinmont. Ivarzn. Svambenzen & 25.615200 & & & 25.615200 \\
\hline Bazyz Ponvosustan Invonteris Kentoe & 1325.000 & & & 1325.000 \\
\hline Bazyz Ponyourotzen Modin den Peralatzen & 550,000 & & & 350.000 \\
\hline Bizyz Amortinzoi bizyza Pra Oporzai & 100000 & & & 100.000 \\
\hline Bazyz Ponveavtzen Invontzris Kondzrzen & 3.500 .150 & & & 3.900 .150 \\
\hline Toral Biava Umem \& Administrani & 1.322 .955 .590 & 35.000 .000 & & 1.257 .955 .590 \\
\hline Pengbarilan noto dari esaba & 6.525 .905 .210 & 35.000 .000 & & 6553.905 .210 \\
\hline \multicolumn{5}{|l|}{ Pendapacan Nion Uxaba } \\
\hline Deriden deri PT. Deta Benmi & 35.000000 & 15.000 .000 & & $100,000.000$ \\
\hline Inaz Giro Bant: Mandiri & 2000.000 & & 2000,000 & \\
\hline Jemlab Peodapatan Non Uraba & $87,000,000$ & 15.000 .000 & 2.000 .000 & $100.000,000$ \\
\hline Bazyz dahoer wazha & $\begin{array}{r}0,00 \\
\end{array}$ & & & \\
\hline Laba Sebelem Paial & 6.615 .905 .210 .00 & $50,000,000$ & 2.000 .000 & 6.653 .905 .210 \\
\hline
\end{tabular}

Sumber : PT. Citra Damai Putra

7. Peredaran Usaha : 7.851.794.100

Laba Sebelum Pajak : 6.615 .808 .210

Koreksi Positif $: 50.000 .000(+)$

Dasar Pengenaan Pajak (DPP) : 6.665 .808 .210

Pembulatan DPP : 6.665 .808 .000

8. PPh Terutang

a. Bagian penghasilan kena pajak atau dasar pengenaan pajak yang memperoleh fasilitas adalah sebesar

$$
\text { (Rp4.800.000.000/Rp7.851.794.100)xRp6.665.808.000 }
$$


$=\mathrm{Rp}$ 4.074.976.750.-

$\mathrm{PPh}$ terutang $=50 \% \times 25 \% \times \mathrm{Rp} 4.074 .976 .750$

$=\operatorname{Rp} 509.372 .094$.

b. Bagian penghasilan kena pajak atau dasar pengenaan pajak yang tidak memperoleh fasilitas adalah sebesar $(\operatorname{Rp} 6.665 .808 .000$

$-\operatorname{Rp} 4.074 .976 .750)=\operatorname{Rp} 2.590 .831 .250$;

PPh Terutang sebesar 25\% x Rp 2.590.831.250

$=\operatorname{Rp} 647.707 .813$

c. Total PPh terutang Rp509.372.094 +Rp 647.707.813

$=\operatorname{Rp} 1.157 .079 .907$

Berikut ini adalah penerapan perhitunganPPh Pasal 21 dengan Metode Gross Up dan pengaruhnya terhadap PPh Badan PT. Citra Damai Putra tahun 2011:

Tabel 4.11

Rekonsiliasi Fiskal

Tahun 2011

\begin{tabular}{|c|c|c|c|c|}
\hline \multirow[t]{2}{*}{ Kotorzenzen } & \multicolumn{3}{|c|}{ Korolod Finiczl } & \multirow[b]{2}{*}{ Koroibui Finkal } \\
\hline & Koemorsiz! & oocisif & Nonzif & \\
\hline \multicolumn{5}{|l|}{ Pondapatan } \\
\hline Ponjuglen & 9.794 .655 .200 & & & 9.794 .655 .200 \\
\hline Herra polvot Peajaglen & 1352750550 & & & 1352750550 \\
\hline Totzl Pondzoztan Uszhn & 8.431 .914 .650 & & & 8.431 .914 .680 \\
\hline \multicolumn{5}{|l|}{ Biava Umem dan Admieistravi } \\
\hline Bizyz Gaij Karyzman dan THR & 1.702 .672 .658 & & & 1. 102.672 .65 \\
\hline Traiznazn Paizí & 112830318 & & & 112330318 \\
\hline Bizyz Liatric den Pam & 4327.355 & & & 4527365 \\
\hline Bizyz Pennobatan ditnrapena Poruazhuen & 25.000000 & 25.000 .000 & & 0 \\
\hline 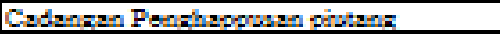 & 7.000 .000 & 7.000 .000 & & 0 \\
\hline Bizyz Tol Bonain den Parkir & 53.735 .794 & & & 55.735 .794 \\
\hline Sonicei Adm Paiji & 12000000 & 12000000 & & 0 \\
\hline Bizyz Ponzirimingen TIKI & 520.000 & & & $\$ 20.000$ \\
\hline Biayz Tolon den Fax & 10974243 & & & 10974243 \\
\hline Biave Hizodohone & 50.155315 & & & 50.155315 \\
\hline Bizya Internet & 3.972 .573 & & & 3,972573 \\
\hline Bizyz Entertzinment. Isran. Srambenazn & 30.250 .400 & & & 30250.400 \\
\hline Bizya Ponyoustan Invontaris Kantor & 2500.000 & & & 2500000 \\
\hline Bazyz Pocryastan Mouin den Poralatan & 750.000 & & & 730.000 \\
\hline Bizyz Anoortisudi bizyza Pra Oporzad & 500.000 & & & $\$ 00.000$ \\
\hline Bizyz Ponyoustan Invontzris Konderzen & 3.075 .000 & & & 5.075 .000 \\
\hline Total Biava Unmem \& Admisistravi & 1.624 .453 .955 & 44.000 .000 & & 1.590 .453 .956 \\
\hline Pesgharilan noto dari vasha & 6.907 .450 .694 & 44.000 .000 & & 6.851 .450 .694 \\
\hline \multicolumn{5}{|l|}{ Perdapacan Non Usaba } \\
\hline Deriden deri PT. Deta Bromi & 90.000000 & 20.000 .000 & & 110.000 .000 \\
\hline Iasz Giro Bank Mandiri & 3500,000 & & 3500.000 & \\
\hline Jemlab Pesdapatan Non Uxaba & 93500.000 & 20.000 .000 & 3500.000 & 110.000 .000 \\
\hline Bizyz diltser wazha & 0.00 & & & 0 \\
\hline Laba Sobelem Paial & 6900950.694 .00 & 64.000 .000 & 3500.000 & 6951.450 .694 \\
\hline
\end{tabular}

Sumber : PT. Citra Damai Putra 
9. Peredaran Usaha

Laba Sebelum Pajak

Koreksi Positif

Dasar Pengenaan Pajak (DPP)

Pembulatan DPP
: 8.431.914.650

: 6.900 .950 .694

$: \underline{64.000 .000(+)}$

: 6.964.950.694

: 6.964 .951 .000

10. PPh Terutang

a. Bagian penghasilan kena pajak atau dasar pengenaan pajak yang memperoleh fasilitas adalah sebesar

(Rp4.800.000.000/Rp8.431.914.650)xRp 6.964.951.000

$=\operatorname{Rp} 3.964 .907 .875 .-$

$\mathrm{PPh}$ terutang $=50 \% \times 25 \% \times \mathrm{Rp} 3.964 .907 .875$

$=\operatorname{Rp} 495.613 .484$.

b. Bagian penghasilan kena pajak atau dasar pengenaan pajak yang tidak memperoleh fasilitas adalah sebesar (Rp 6.964.951.000-Rp 3.964.907.875) =Rp 3.000.043.125;

PPh Terutang sebesar 25\% x Rp 3.000.043.125

$=\operatorname{Rp} 750.010 .781$

c. TotalPPhterutangRp495.613.484+Rp 750.010.781

$=\operatorname{Rp} 1.245 .624 .265$

Berikut ini adalah penerapan perhitunganPPh Pasal 21 dengan Metode Gross Up dan pengaruhnya terhadap PPh Badan PT. Citra Damai Putra tahun 2012: 
Tabel 4.12

Rekonsiliasi Fiskal

Tahun 2012

\begin{tabular}{|c|c|c|c|c|}
\hline \multirow{2}{*}{ Koverzaren } & \multicolumn{3}{|c|}{ Korgkai Fiakzl } & \multirow[b]{2}{*}{ Koroboi Fitizal } \\
\hline & Komberaigl & pocistif & Nozasif & \\
\hline \multicolumn{5}{|l|}{ Pendepaten } \\
\hline Ponjoglen & 10.594 .400 .300 & & & 10.594 .400 .300 \\
\hline Ferze pobot Penisalen & 1.432 .454 .255 & & & 1.432 .454 .255 \\
\hline Total Pendepatan Usahs & 9.451 .945 .045 & & & 9.451 .945 .045 \\
\hline \multicolumn{5}{|l|}{ Biava Umem dan Administrai } \\
\hline Bizyz Gaij Karyzwen den THR & 1. 600.770 .720 & & & 1. 600.770 .720 \\
\hline Bazyz PPh Pasil 21 & 149.720 .274 & & & 149.720 .274 \\
\hline Bizyz Liatric den Pam & 6.349 .405 & & & 6349.405 \\
\hline Bizyz Ponaobaten dinazenz Persazhrem & 23.0000000 & 23.000 .000 & & 0 \\
\hline Cadznzan Penzhropossen pistang & 10.000 .000 & $10.000,000$ & & 0 \\
\hline Basya Tol Bongin den Parkir & 61.356 .117 & & & 61.356 .117 \\
\hline Sankibi Adm Paiz & 14.000 .000 & 14.000 .000 & & 0 \\
\hline Bazyz Penziriminzen TIKI & 650.000 & & & 650.000 \\
\hline Bazyz Tolon den Fax & 12549.163 & & & 12549.163 \\
\hline Biayz Hindohoon & 60.525 .413 & & & 60.525 .413 \\
\hline Bizyz Internet: & 4.453 .992 & & & 4.483 .992 \\
\hline Bazyz Entortzinmont, Ivazn, Szambanazn & 35.998 .700 & & & 35.998 .700 \\
\hline Bazyz Penyouvtan Inventaris Kantor & 2870500 & & & 2570500 \\
\hline Basya Penvoustan Movin den Peralaten & 1.000 .000 & & & 1.000000 \\
\hline Bizyz Amortinzei bizyz Pra Oporzei & 850.000 & & & 350,000 \\
\hline Bizyz Ponyoustan Inventaris Kondzrazn & 8.569.000 & & & 8.569.000 \\
\hline Total Biava Unerm \& Administrai & 1.857 .293 .284 & 52.000 .000 & & 1.835 .293 .284 \\
\hline Pesghasilan neto dari waba & 7.564 .652 .761 & 52.000 .000 & & 7.616 .652 .761 \\
\hline \multicolumn{5}{|l|}{ Pesdapatan Non Usaba } \\
\hline Deviden deri PT. Deta Bumi & 100.000000 & 25.000 .000 & & 125.000000 \\
\hline Jus Giro Bent Mandiri & 5.000 .000 & & 5.000 .000 & \\
\hline Jemlab Peadapatan Non Usaba & 105.000 .000 & 25.000 .000 & 5.000 .000 & 125.000 .000 \\
\hline Bizyz dihas washe & 0,00 & & & \\
\hline Laba Sebelem Pajak & 7.659 .652 .761 .00 & & 5000 & 7.741 .652 .761 \\
\hline
\end{tabular}

Sumber : PT. Citra Damai Putra

11. Peredaran Usaha

Laba Sebelum Pajak

Koreksi Positif

Dasar Pengenaan Pajak (DPP)

Pembulatan DPP
: 9.451 .946 .045

: 7.669.652.761

$: \underline{77.000 .000(+)}$

: 7.746.652.761

: 7.746.653.000

12. PPh Terutang

a. Bagian penghasilan kena pajak atau dasar pengenaan pajak yang memperoleh fasilitas adalah sebesar

(Rp4.800.000.000/Rp9.451.946.045)xRp7.746.653.000

$=\operatorname{Rp} 3.933 .997 .742$.-

$\mathrm{PPh}$ terutang $=50 \% \times 25 \% \times \mathrm{Rp} 3.933 .997 .742$

$=\operatorname{Rp} 491.749 .718 .-$ 
b. Bagian penghasilan kena pajak atau dasar pengenaan pajak yang tidak memperoleh fasilitas adalah sebesar ( $\mathrm{Rp}$ 7.746.653.000-Rp 3.933.997.742) =Rp 3.812.655.258;

PPh Terutang sebesar 25\% x Rp 3.812.655.258

$=\operatorname{Rp} 953.163 .815$

c. Total PPh terutang Rp491.749.718 +Rp 953.163.815

$=\operatorname{Rp} 1.444 .913 .533$

Perbandingan Penghematan Pajak PPh Pasal 21 dengan Metode Net dan Metode Gross Up Terhadap PPh Terutang

Tabel 4.13

PerbandinganPPh TerutangMetodeNet danGross up PT. Citra Damai Putra

Tahun 2010

\begin{tabular}{|c|c|c|c|}
\hline Keterangan & $\begin{array}{c}\text { Metode Net } \\
\text { PPhPasal 21 } \\
\text { Ditanggung }\end{array}$ & $\begin{array}{c}\text { PPhPasal 21 } \\
\text { Di-Gross up }\end{array}$ & $\begin{array}{c}\text { EfekPajakYang } \\
\text { Dibayar }\end{array}$ \\
\hline PPh Pasal 21 & 64.646 .184 & 74.423 .168 & Naik 9.776.984 \\
\hline PPh Badan & 1.169 .998 .574 & 1.157 .079 .907 & Turun 12.918.667 \\
\hline PPh Terutang & 1.234 .644 .758 & 1.231 .503 .075 & Turun 3.141.683 \\
\hline
\end{tabular}

Sumber : Data Olahan

Dari analisis diatas dengan menggunakan perhitungan Pajak Penghasilan digross up, perhitungan Pajak Penghasilan Pasal21 akan naik sebesar $\mathrm{Rp}$ 9.776.984 dan perhitungan Pajak Penghasilan Badan akan turun sebesar Rp 12.918.667, Dengan hasil tersebut maka perusahaan akan mendapatkan penghematan pajak sebesar Rp3.141.683. 
Tabel 4.14

PerbandinganPPh TerutangMetodeNet danGross up

PT. Citra Damai Putra

Tahun 2011

\begin{tabular}{|c|c|c|c|}
\hline \multirow{2}{*}{ Keterangan } & $\begin{array}{c}\text { Metode Net } \\
\text { PPhPasal 21 } \\
\text { Ditanggung }\end{array}$ & $\begin{array}{c}\text { PPhPasal 21 } \\
\text { Di-Gross up }\end{array}$ & $\begin{array}{c}\text { EfekPajakYang } \\
\text { Dibayar }\end{array}$ \\
\hline PPh Pasal 21 & 93.862 .034 & 112.830 .318 & Naik 18.968.284 \\
\hline PPh Badan & 1.266 .106 .478 & 1.245 .624 .265 & Turun 20.482.213 \\
\hline PPh Terutang & 1.359 .968 .512 & 1.358 .454 .583 & Turun 1.513.929 \\
\hline
\end{tabular}

Sumber : Data Olahan

Dari analisis diatas dengan menggunakan perhitungan Pajak Penghasilan digross up, perhitungan Pajak Penghasilan Pasal21 akan naik sebesar Rp18.968.284 dan perhitungan Pajak Penghasilan Badan akan turun sebesar Rp 20.482.213, Dengan hasil tersebut maka perusahaan akan mendapatkan penghematan pajak sebesar Rp1.513.929

Tabel 4.15

PerbandinganPPh TerutangMetodeNet danGross up PT. Citra Damai Putra

Tahun 2012

\begin{tabular}{|c|c|c|c|}
\hline Keterangan & $\begin{array}{c}\text { Metode Net } \\
\text { PPh Pasal 21 } \\
\text { Ditanggung } \\
\text { Perusahaan }\end{array}$ & $\begin{array}{c}\text { PPhPasal 21 } \\
\text { Di-Gross up }\end{array}$ & $\begin{array}{c}\text { EfekPajakYang } \\
\text { Dibayar }\end{array}$ \\
\hline PPh Pasal 21 & 119.948 .176 & 149.720 .274 & Naik 29.772.098 \\
\hline PPh Badan & 1.472 .838 .898 & 1.444 .913 .533 & Turun 27.925.365 \\
\hline PPh Terutang & 1.592 .787 .074 & 1.594 .633 .807 & Naik 1.846.733 \\
\hline
\end{tabular}

Sumber : Data Olahan

Dari analisis diatas dengan menggunakan perhitungan Pajak Penghasilan digross up, perhitungan Pajak Penghasilan Pasal 21 akan naik sebesar Rp 29.772.098 dan perhitungan Pajak Penghasilan Badan akan turun sebesar Rp 27.925.365, Dengan hasil tersebut maka perusahaan akan mendapatkan penghematan pajak sebesar Rp1.846.733. Sedangkan di sisi lain, perubahan kebijakan perpajakan tersebut justru akan meningkatkan motivasi karyawan karena Take Home Pay karyawan akan ikut naik. Dengan terdongkraknya motivasi 
karyawan, tentu saja diharapkan produktivitas dan kinerja karyawan akanmeningkat dan pada gilirannya akan memberikan dampak pada peningkatan omzet usaha PT. Citra Damai Putra.

\section{KESIMPULAN}

Berdasarkan analisis masalah sebagaimana terdapat pada bab IV yang dihubungkan dengan landasan teori,undang-undang,serta peraturan perpajakan yang terkait, dapat ditarik kesimpulan sebagai berikut:

Dari perbandingan perhitungan Pajak Penghasilan (PPh) Pasal 21 dengan menggunakan Metode Net atau Metode Gross-up yang paling efisien adalah dengan metode gross-up atau pemberian tunjangan sebesar pajak terutangnya, sehingga perusahaan lebih menguntungkan menggunakan metode Gross up dibandingkan dengan menggunakan metode net. Dari perbandingan kedua perhitungan yang dilakukan, metode gross-up atau pemberian tunjangan sebesar pajak terutangnya menghasilkan efisiensi terhadap Pajak Penghasilan(PPh) Badan sebesar Rp 3.141.683 untuk tahun 2010, Rp 1.513.929untuk tahun 2011, dan Rp1.846.733untuk tahun 2012.

\section{DAFTAR PUSTAKA}

Amin Rochmat ( 2013), “Pajak terapan Brevet A\&B”, Bina Fiskal Indonesia, Jakarta

B. Ilyas Wirawan ( 2010 ), “Hukum Pajak”, Jakarta, Salemba Empat Bungin Burhan (2005), "Metodologi Penelitian Kuantitatif, Komunikasi, Ekonomi, dan Kebijakan Publik serta ilmu Sosial Lainnya”, Jakarta, Kencana Prenada Media Group

Direktorat Jenderal Pajak Undang-Undang Nomor 7 Tahun 1983 sebagaimana telah diubah, terakhir dengan Undang-Undang Nomor 36 Tahun 2008 tentang Pajak Penghasilan

Direktorat JenderalPajakUndang-UndangNomor 6Tahun1983sebagaimana telah diubah, terakhir dengan Undang-Undang Nomor 28 Tahun 
2007 tentang Ketentuan Umum dan Tata Cara Perpajakan beserta Aturan Pelaksanaannya

Hardika, Nyoman sentosa (2007), "Perencanaan Pajak Sebagai Strategi Penghematan Pajak”, Jurnal Bisnis Dan Kewirausahaan, Vol.3, No.2, Hal103-112, Juli,

Harnanto (2013), “Perencanaan Pajak”, Yogyakarta, Fakultas Ekonomi dan Bisnis UGM

Mardiasmo (2009), “Perpajakan”, Andi Yogyakarta, Yogyakarta

Omposunggu, Arles. (2011), “Cara Legal Siasati Pajak”, Jakarta, PuspaSwara.

Pohan, Chairil Anwar. "Optimizing Corporate Tax Management: Kajian Perpajakan Dan Tax Planning-Nya Terkini”, Bumi Aksara, Jakarta, 2011.

Priantara Diaz ( 2013), "Perpajakan Indonesia”, Jakarta, Mitra Wacana Media

Rocmat Soemitro (1988), “Pajak Internasional”, Jakarta, PT.Gramedia

Setiawan Agus (2008), "Cara Mudah Menghitung PPh Badan Dengan Undang-Undang pajak terbaru”, Jakarta, Artika Maya Suandy Erly. (2008) “Hukum Pajak Edisi4”, Jakarta, Salemba Empat.

Sugiono (2012). "Makro Ekonomi”, Rajawali, Yogyakarta

Suriasumantri, 1986 (Sugiyono, 2009), “Metodologi Penelitian Bisnis”, Bandung, Alfabeta

Sugiono (2010), “Metode Penelitian Bisnis”, Bandung, Alfabeta.

Zain Muhammad (2008), “Manajemen Perpajakan”, Jakarta, Salemba Empat 